\title{
Radioactivity in produced water from Norwegian oil and gas installations - concentrations, bioavailability, and doses to marine biota
}

\author{
D.Ø. Eriksen ${ }^{1,5}$, R. Sidhu ${ }^{1}$, T. Ramsøy ${ }^{1}$, E. Strålberg ${ }^{1}$, K.I. Iden ${ }^{1}$, H. Rye ${ }^{2}$, \\ K. Hylland ${ }^{3,6}$, A. Ruus ${ }^{3}$ and M.H.G. Berntssen ${ }^{4}$ \\ ${ }^{1}$ Institute for Energy Technology (IFE), Norway \\ ${ }^{2}$ The Foundation for Scientific and Industrial Research at the Norwegian Institute \\ of Technology (SINTEF), Norway \\ ${ }^{3}$ Norwegian Institute for Water Research (NIVA), Norway \\ ${ }^{4}$ National Institute of Nutrition and Seafood Research (NIFES), Norway \\ ${ }^{5}$ Present affiliation: Primus.inter.pares as \\ ${ }^{6}$ Present affiliation: University of Oslo \\ e-mail:d.o.eriksen@kjemi.uio.no
}

\begin{abstract}
Large amount of produced water, containing elevated levels of radionuclides (mainly ${ }^{226} \mathrm{Ra}$ and ${ }^{228} \mathrm{Ra}$ ), is discharged to the sea in connection with oil and gas production on the Norwegian continental shelf. The main objective of this project has been to establish radiological safe discharge limits for radium associated with other components in produced water. We present a summary of the methodology developed and the overall results obtained. Our results show that presence of added chemicals like scale inhibitors in the produced water have a marked influence on the speciation of radium, i.e. formation of radium and barium sulphates when produced water is mixed with seawater. Radium's behaviour in the sea has been modelled using the DREAM model. Also, we have showed that the bioavailability of radium may be increased due to presence of scale inhibitors. Juvenile cod has been exposed to radium through food and from water. The uptake in different organs, i.e. skin, gills, liver, blood, and kidneys, show large variability, but is modest in all organs.
\end{abstract}

\section{INTRODUCTION}

Substantial amounts of produced water $\left(143 \mathrm{Mm}^{3}\right.$ in 2004) is discharged to the sea in connection with oil and gas production on the Norwegian continental shelf. Produced water from some installations contains elevated levels of ${ }^{226} \mathrm{Ra}$ and ${ }^{228} \mathrm{Ra}$.

It is generally assumed that when produced water rich in barium and poor in sulphate is brought into contact with seawater, rich in sulphate, radium will co-precipitate with barium as sulphates. Depending on the size, the particles will either be transported with the water currents, settle immediately, or sorb onto other organic or inorganic particles. Finally, they will reach the seafloor. The speciation of radium is determined by the much higher concentrations of barium. There is however limited data on the speciation of radium, barium, and the organic components in produced water. In today's oil production, chemicals, e.g. scale- and corrosion inhibitors, emulsion breakers and surfactants, and sulphide removers, are added to ease the operation. These chemicals are usually organic compounds comprising functional groups, which may also interact with cations such as $\mathrm{Ra}^{2+}$ and $\mathrm{Ba}^{2+}$. Thus, radium may exist in compounds more easily accessible for uptake in biota than the inorganic aqueous or food-borne form.

Two major contributors to emission to sea from installations on the Norwegian sector are Troll B and C. To avoid the formation of $\mathrm{CaCO}_{3}$ scale at the Troll field, the scale inhibitor SI 4470 (MI Production Chemicals, Norway) is used at an average concentration of about $13 \mathrm{mg} / \mathrm{L}$ produced 
water [Rantrud and Toft 2008]. This is a low molecular weight polycarboxylic acid adjusted to $\mathrm{pH}$ 9-10. Although designed for reaction with $\mathrm{Ca}^{2+}$-ions, it may also interact with dissolved barium and radium. In this manner it may affect the sedimentation and mobility of barium and radium, when discharged produced water mixes with seawater.

An understanding of how different compounds in produced water affect the mobility, bioavailability, and sedimentation of radium is essential in order to determine the fate and effects of radium discharges. Sediment-dwelling organisms may be an important group of marine organisms that might be exposed to the relevant radionuclides. Once taken up by sediment dwelling invertebrates, the nuclides can be transferred to higher level of the marine food chain (fish), ultimately forming a potential risk for human consumption. In addition to the food-borne route of exposure, water-borne exposure would be expected to form an alternative route by which fish can be contaminated. The relative uptake from the different exposure routes as well as the effect of chemicals on the bioavailability of radionuclides is of great importance when assessing possible consequences for animal welfare and food safety. For evaluation purposes the behaviour of radium in produced water must be compared to radium already present naturally in seawater.

\section{METHODS}

The structure of the project is described schematically in Figure 1.

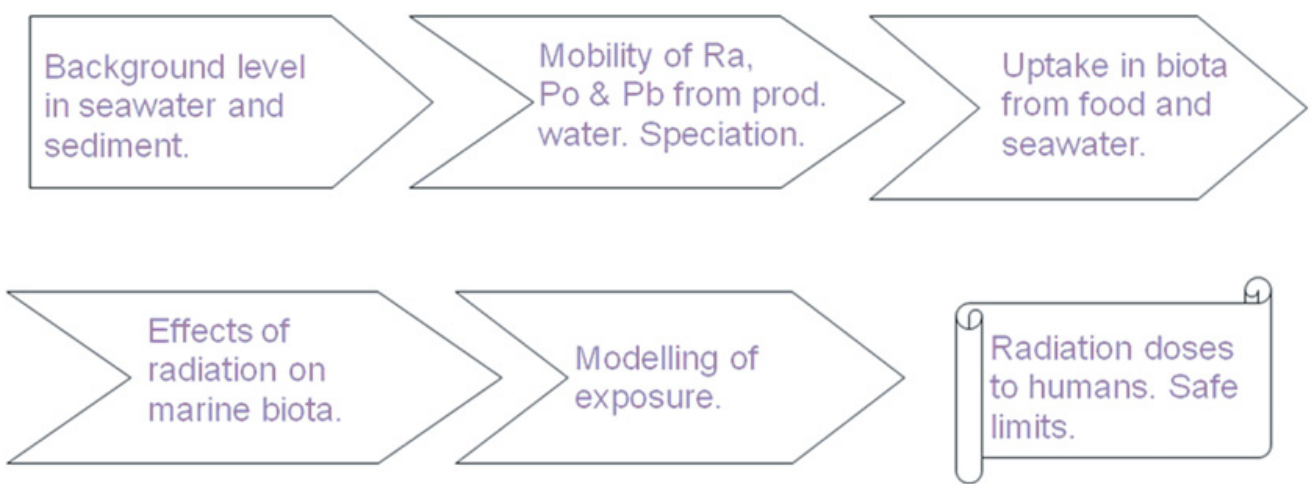

Figure 1. Conceptual structure of project.

The project has consisted of six parts. Part one was a survey of the natural background of Ra. Samples of fish, sediment dwelling organisms, sediments, and seawater samples from various depths and locations were analysed for ${ }^{226} \mathrm{Ra}$. Particle size distributions and mineral morphology of sediment samples were also determined.

Part two focused on the speciation of $\mathrm{Ra}$ in produced water (PW). All PW samples had concentrations of $\mathrm{Ba}$ above $1 \mathrm{mg} / \mathrm{L}$ making $\mathrm{Ba}$ carrier for Ra. Artificial $\mathrm{PW}$ with and without scale inhibitor (SI 4470) was made to measure the difference in particle size of the formed $\mathrm{Ba}(\mathrm{Ra}) \mathrm{SO}_{4}$. Subsequent tests with real PW at Troll were performed.

In part three of the project biota was exposed to ${ }^{226} \mathrm{Ra}$, with and without scale inhibitor added, under controlled conditions where ${ }^{226} \mathrm{Ra}$-concentrations were $10 \mathrm{~Bq} / \mathrm{L}$. All experiments were performed at NIVA's Marine Research Station at Solbergstrand. ${ }^{226} \mathrm{Ra}$ was measured by liquid scintillation (LS) counting using Quantulus low level LS spectrometer at IFE. Juvenile cod was exposed by force feeding to study the uptake through food in the first experiment. During a second experiment juvenile cod was exposed directly from water containing enhanced level of ${ }^{226} \mathrm{Ra}$, with and without scale inhibitor. In the third experiment Hediste, a vertebrate worm, was allowed to live 
in sediments with enhanced level of ${ }^{226} \mathrm{Ra}$ with and without scale inhibitor. All experiments included controls with natural concentration of ${ }^{226} \mathrm{Ra}$ in seawater and sediment.

In part four effects of the radiation from ${ }^{226} \mathrm{Ra}$ on fish eggs and stem cells from cod were studied. Stress indicators, i.e. specific enzymes, were searched for. Cells were exposed to seawater containing $2 \mathrm{~Bq} / \mathrm{L}$ of ${ }^{226} \mathrm{Ra}, 1000$ times the natural background concentration.

Part five was a simulation study of the fate of the radioactivity of PW. The DREAM model was employed to map the movement of the emission. In addition, sedimentation mechanisms and rates were modelled and simulated.

The sixth and final part consisted of an estimation of the doses from radioactivity in PW imposed on marine biota and recommendations for human intake. The estimates used the acquired data as input.

\section{EXPERIMENTAL}

The particles size distributions of the sediment samples were determined by laser scattering using a Malvern Mastersizer 2000. The morphologies of the particle fractions were studied using SEM, Hitachi S4800.

Foodborn bioavailability is defined as the fraction of an orally administered dose reaching the systemic circulation of the animal [McClosky, 1998]. It can be quantified (in \% uptake from feed) by the integral of the concentration of $\mathrm{Ra}$ in blood as a function of time after a single dose. This can thus be determined by comparing the calculated area under concentration vs. time curves (AUC) for Ra from food or injected directly into the blood. To enable measurement of uptake of ${ }^{226} \mathrm{Ra}$ in fish through food, ${ }^{226} \mathrm{Ra}$ with and without scale inhibitor was added to fish food. The fish (juvenile Atlantic cod (Gadus morhua)) were force fed orally by administering a dose of food directly into the stomach with a syringe. The amount of food depended on the weight of the fish so that all fishes were exposed to the same dose. Samples of blood were then taken at pre-determined times. Also for the exposure of fish from water, juvenile cod was used. The fish were sampled at pre-determined times and samples of gills, skin, kidneys, liver and blood were collected [Eriksen et al., 2006].

Liquid scintillation counting was used for measuring ${ }^{226} \mathrm{Ra}$ and daughters, 90 minutes counting per sample was used for all. The samples were stored until radioactive equilibrium was obtained. They were dissolved in 1-2 mL Solvable and $20 \mathrm{~mL}$ UltimaGold AB was added. Both solutions were purchased from Perkin Elmer. Using Quantulus (LKB Wallac Oy) with peak shape analysis a good separation of alpha- and beta-radiation was obtained. Although the quenching in some samples was considerable, the loss of alphas seems to be low. For each spectrum the background was subtracted and the peak area defined manually. Then the integral was calculated. However, the total integral was not divided by four to correct for the contribution from the daugthers. This is only important to consider when comparing results based on other measuring methods. At each sampling time three or four samples were taken. There were also always control groups.

${ }^{226} \mathrm{Ra}$ in sediment and fish samples was determined by gamma spectrometric (HPGe) analysis of the daughters ${ }^{214} \mathrm{~Pb}$ and ${ }^{214} \mathrm{Bi}$ after a minimum of three weeks storage in appropriate air tight containers.

${ }^{226} \mathrm{Ra}$ in seawater and sediment dwelling organisms was determined by alpha spectrometry with ${ }^{133} \mathrm{Ba}$ as tracer. $\mathrm{Ra}$ in seawater samples was pre-concentration by $\mathrm{MnO}_{2}$ precipitation followed by sulphate precipitations and a final $\mathrm{BaSO}_{4}$ micro co-precipitation.

\section{RESULTS}

The results from the background survey for sediments are presented in Figure 2 also showing two examples of particle distributions from the western and shallow sea depths at $100 \mathrm{~m}$ (upper) and the eastern and deep sea at $>200 \mathrm{~m}$ (lower). The smaller particles contain the highest level of Ra.

Little information is available on the levels of ${ }^{226} \mathrm{Ra}$ in the North Sea. IAEA (1990) have reported relatively high activity concentrations $(6.7-8.5 \mathrm{mBq} / \mathrm{L})$, but no information has been given about the 

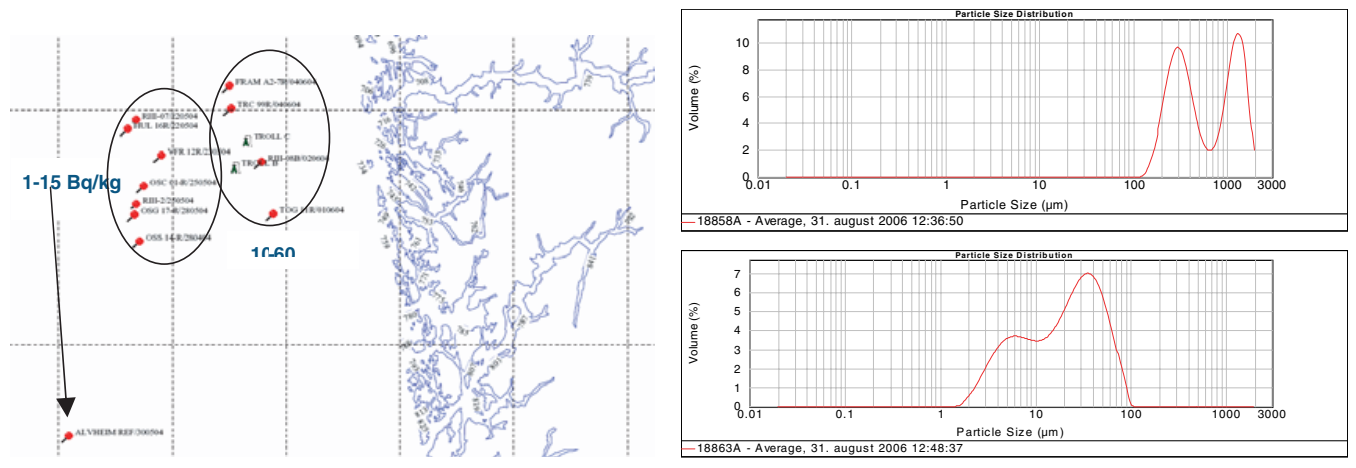

Figure 2. The sampling sites for sediments and also for sediment and seabed dwelling biota. The western sites at about $100 \mathrm{~m}$ depth contained $1-15 \mathrm{~Bq} / \mathrm{kg}{ }^{226} \mathrm{Ra}$ in the sediments, whereas the eastern sites at $>200 \mathrm{~m}$ depth contained $10-60 \mathrm{~Bq} / \mathrm{kg}$. To the right in the figure size distributions of typical samples are displayed. At the western sample sites typical minerals are: quartz, calcite, plagioclase, K-feldspar (coarser grain size) vs. the eastern ones containing: quartz, mica, calcite, K-feldspar, dolomite/ankerite.

sample locations. Samples from the North Sea collected by the NRPA in 2002, 2004 and 2005 show ${ }^{226} \mathrm{Ra}$ concentrations in the ranges $1-2.5,1.0-2.9$ and $0.9-5.1 \mathrm{mBq} / \mathrm{L}$ respectively (Gäfvert et al., 2004, 2006, 2007). The ${ }^{226} \mathrm{Ra}$ concentration for the Atlantic Ocean (top 500 meters) varies from 0.74 to $2.96 \mathrm{mBq} / \mathrm{L}$ (IAEA 1990). Due to leaking from coastal sediments the concentration of radium is higher in coastal areas than in the open sea $(0.74-5.55 \mathrm{mBq} / \mathrm{L}$, IAEA 1990).

Results for the analyses of radium in the seawater samples showed that the measured concentrations are in the higher part of previously reported activity ranges (above). One possible explanation for this might be that our results include radium adsorbed to particles in the water.
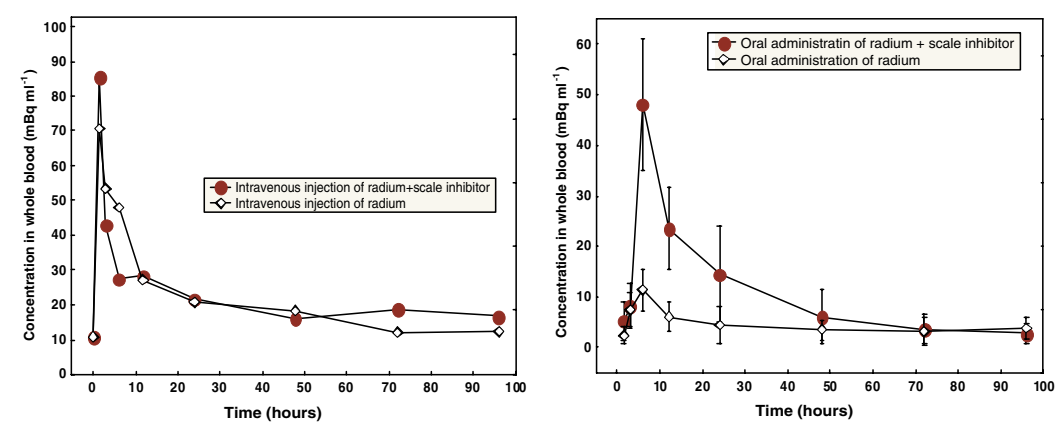

Figure 3. Uptake of radium in juvenile cod from feed with, and without scale inhibitor, SI 4470. The left hand side shows the concentration as a function of time of $\mathrm{Ra}$ and $\mathrm{Ra}+$ scale inhibitor after intravenous injection, and the right hand side shows the corresponding spectra after exposure through food.

Samples of fish taken at the North Sea, Lofoten, and the Barents Sea showed radium concentrations of $<0.5 \mathrm{~Bq} / \mathrm{kg}$ for ${ }^{226} \mathrm{Ra}$. Sediment dwelling organisms showed concentrations of Ra corresponding to the level in the sediments. This can be explained by the fact that the animals were not depurated, and that their intestines were filled with sediment particles at the time of analyses. All together, the background survey showed normal activity levels in sediment, seawater and biota.

The results from the controlled exposures of juvenile cod are shown in figures 3 and 4 . Both show that presence of scale inhibitor alters the chemical behaviour of Ra. The uptake from food is enhanced a factor of $5(60 \%)$ for Ra with scale inhibitor compared to $12 \%$ without. There is an indication 

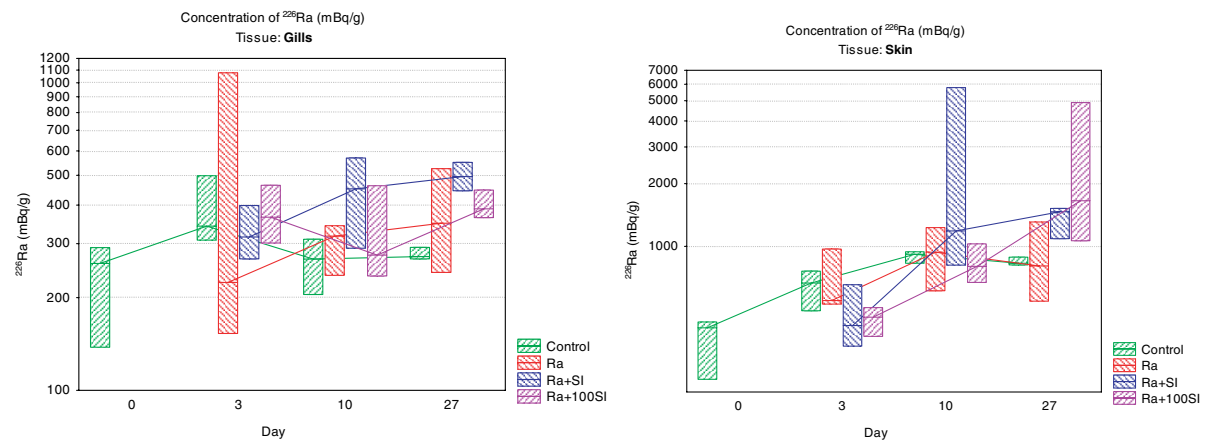

Figure 4. Uptake of radium in juvenile cod from sea water with, and without scale inhibitor, SI 4470. Samples were collected from blood, liver, skin and gills after specific periods. The figure shows the data for gills and skin. Three species from each group were collected each time. The plot show maximum, minimum and median values for each group at the sampling times.

(Figure 4) that Ra from water is accumulated in the fish skin. This effect is also enhanced by presence of scale inhibitor.

Cod stem cells were exposed to $\mathrm{NaCl}$-solution containing $2 \mathrm{Bg} / \mathrm{L}{ }^{226} \mathrm{Ra}$, i.e. 1000 times higher concentration than in natural sea water. After 48 hours there were an increased concentration of the two stress hormones HSP70 and GSH-Px whereas others did not show any sign of stress. The experiment will be repeated and the use of the used indicators studied in more detail.

\section{CONCLUSIONS}

Polikarpov's (1998) conceptual model for radiation doses to biota states that doses under normal background levels are in the range $40 \mu \mathrm{Gy} / \mathrm{y}-5 \mathrm{mGy} / \mathrm{y}$. Doses to biota from discharge of produced water has been calculated to be far less than this. Even for fish hypothetically living in produced water with an activity concentration of $10 \mathrm{~Bq} / \mathrm{L}$ for ${ }^{226} \mathrm{Ra}$, similar to that from Troll (seawater $1-5 \mathrm{mBq} / \mathrm{L}$ ), the external dose will be only $\sim 80 \mu \mathrm{Gy} / \mathrm{y}$. No effects on biota can therefore be expected from the discharge of produced water from oil and gas installations at the Norwegian continental shelf.

The results did not show any indications on enhanced risks for increased doses to humans due to intake of fish from the North Sea. The effects will be far below detection limit and therefore it will not make any sense to define PNEC-values (Predicted No Effect Concentrations).

We conclude:

- Concentrations of ${ }^{226} \mathrm{Ra}$ in the North Sea water and biota are generally low, but are more varying in sediments. The cause of the variations seems to be related to the size of the sediment particles, thus also correlated to the depth of the sediments.

- Chemicals, i.e. scale inhibitors, present in produced water alter the speciation properties of barium and radium.

- $\mathrm{Ba}(\mathrm{Ra}) \mathrm{SO}_{4}$ is much more difficult to precipitate in seawater than anticipated due to dilution. Scale inhibitors enhance this effect.

- Presence of scale inhibitors increases the ability of Ra to be taken up by biota, e.g. fish.

- Sediment dwelling organisms get enhanced concentration of Ra if sediment level increases.

- Today's level of produced water discharges represents insignificant risk for biota and humans.

\section{Acknowledgments}

The collaboration is grateful for a grant from the Research Council of Norway (NFR) and support from the Association of Norwegian Oil Industry (OLF) and StatoilHydro. 


\section{References}

[1] Eriksen, D.Ø., Sidhu, R., Strålberg, E., Iden, K.I., Hylland, K., Ruus, A., Røyset, O., Berntssen, M.H.G., Rye H. "Radionuclides in produced water from Norwegian oil and gas installations - concentrations and bioavailability"- Proceedings of the $15^{\text {th }}$ Radiochemical Conference, Czechoslovak Journal of Physics (2006) Vol. 56, Suppl. D, D43-D48

[2] IAEA (1990). The environmental behaviour of radium, Vol. I-II. Technical report series no. 310. International Atomic Energy Agency

[3] Gäfvert T., Føyn L., Brungot A.L., Kolstad A.K., Lind B., Gwynn J., Sværen I., Alvestad P., Skipperud L., Strålberg E., Christensen G.C., Salbu B., Drefvelin J., Dowdall M., Rudjord A.L. Radioactivity in the Marine Environment 2002. Results from the Norwegian National Monitoring Programme (RAME), NRPA Report 2004:10

[4] Gäfvert T., Sværen I., Brungot A.L., Kolstad A.K., Lind B., Gwynn J., Alvestad P., Heldal H E., Føyn L., Strålberg E., Christensen G.C., Skipperud L., Salbu B., Drefvelin J., Dowdall M., Rudjord A.L. (2006). Radioactivity in the Marine Environment 2004. Results from the Norwegian Marine Monitoring Programme (RAME). StrålevernRapport 2006:14, Norwegian Radiation Protection Authority (NRPA)

[5] Gäfvert T., Sværen I., Gwynn J., Brungot A.L., Kolstad A.K., Lind B., Alvestad P., Heldal H.E., Strålberg E., Christensen G.C., Drefvelin J., Dowdall M., Rudjord A.L. (2007). Radioactivity in the Marine Environment 2005. Results from the Norwegian Marine Monitoring Programme (RAME). StrålevernRapport 2007:10, Norwegian Radiation Protection Authority (NRPA)

[6] Polikarpov G.G. (1998). Conceptual model of responses of organisms, populations and ecosystems in all possible dose rates of ionising radiation in the environment. RADOC 96-97, Norwich/Lowestoft, 8-11 April 1997. Radiation Protection Dosimetry 75, 181-185

[7] McCloskey, J.T., Schultz, I.R., Newman, M.C. (1998) Estimating the oral bioavailability of methylmercury to channel catfish (Ictalurus Punctatus). Environ. Toxicol. Chem. 17, 1524-1529

[8] Rantrud, Ø. and Toft, J. (2008) Årsrapport til SFT. Utslipp til sjø og luft, samt avfall fra Troll B, Troll C og Fram. StatoilHydro AU-EPN ONS TRO-00060 